\title{
Pollen, women, war and other things: reflections on the history of palynology
}

\author{
Kevin J. Edwards ${ }^{1,2}$ (1) \\ Received: 14 April 2017 / Accepted: 31 July 2017 / Published online: 8 August 2017 \\ (C) The Author(s) 2017. This article is an open access publication
}

\begin{abstract}
The development of palynology since its recognised launch in 1916 by Lennart von Post is examined in terms of its historiography, the biographies of pollen analysts and the role of those who have influenced the discipline. Emphasis is placed upon research beginnings in Scandinavia (especially Sweden), Great Britain and Ireland. Within an analytical narrative which includes archival and published sources, special consideration is given to a 'proclamation' on methodology which appeared in 1909, on a supposed geology/botany dichotomy stemming from von Post's background, on the forgotten early practitioners in Britain and Ireland and their connections, on the role of women up to the end of the Second World War and on issues related to wartime hostilities. Present day palynology can trace a continuity from von Post and palynologists are part of an extended disciplinary genealogy. Ignorance of these can be seen as a loss of heritage and to represent an intellectual impoverishment.
\end{abstract}

Keywords Lennart von Post · Gustaf Lagerheim · Gunnar Erdtman · Palynology $\cdot$ Historiography $\cdot$ Pioneers $\cdot$ Biographies

\section{Introduction}

Since its recognised launch in 1916 (von Post 1916a [a summary with discussion], fully published as Von Post 1918), pollen-based palynology has had a generally positive billing. Roberts's (2014, p. 33) statement that palynology is "the single most important branch of terrestrial palaeoecology for the late Pleistocene and Holocene' will presumably be agreeable to most of us. Ed Deevey's (1967, p. 65) observation that it 'must rank with the double helix as one of the most productive suggestions of modern times' is perhaps too hyperbolic for some, but it was written before the explosion in molecular biology and we should credit pollen analysis with its achievements and potential. If the field should be in danger of hubris, it might harken also to critical voices (Welinder 1988; Kullman 2001, 2008).

Communicated by H. J. B. Birks.

Kevin J. Edwards

kevin.edwards@abdn.ac.uk

1 Departments of Geography and Environment and Archaeology, School of Geosciences, University of Aberdeen, Elphinstone Road, Aberdeen AB24 3UF, UK

2 Clare Hall, University of Cambridge, Herschel Road, Cambridge CB3 9AL, UK
An appreciation of the paths taken within disciplines can be gleaned by historiographical study, whereby we examine the ways that things are written, presented, interpreted and even ignored. As pollen analysis passes its centenary (Birks et al. 2016; Edwards et al. 2017), it seems pertinent to look at some of the elements of this journey. This is illustrated mainly with reference to the beginnings of the discipline within its Scandinavian homeland and within the British Isles - a geographical and temporal focus which is not intended to downplay the great contributions from elsewhere or in later times. The selection of these areas reflects the hearth of the pollen method (Sweden) and its early adoption within a European arena with which the author is familiar. Archival data exist for both areas, although such evidence has yet to be quarried comprehensively. These histories involve biographies, personalities and actions. Aspects of some of these are presented because they have been forgotten-if they were ever seriously known-by many current practitioners.

As we shall see, Gustaf Lagerheim was a seminal influence on Lennart von Post, the purported father of pollen analysis. Lagerheim, a Swede, contributed pollen data to research by botanist Gunnar Samuelsson in Great Britain and geologist Nils Holst in Sweden at a time in the early 20th century when the formulation of the pollen method was being promulgated. In spite of this symbiotic use of pollen 
(and spore) data by botanists and geologists, there has arisen a perception that the field developed dichotomously-first geologically and then botanically/ecologically. This surmise is scrutinized.

The practitioners mentioned so far have all been men, but women played a vital role in the history of pollen analysis. Arguably, they have not been the invisible brigade which has suffused other scientific fields. Social considerations of a different sort might be expected in wartime and this is explored in terms of Quaternary pollen-analytical output during and either side of the Second World War. In spite of the disruption caused by global hostilities, a continuity of productivity is evident, although this was interrupted for some countries as the conflict endured.

The opportunity is also taken to navigate professional relationships. In order to appreciate more fully the cast of characters, this treatment will sometimes address areas of their lives which are not strictly palynological. Constraints of space mean that this account must be highly selective and it is hoped that some encouragement will be provided for others to delve into the little-explored, but multi-faceted 'archives' of palynology.

\section{Gustaf Lagerheim, Lennart von Post, a key proclamation and other beginnings}

Ernst Jakob Lennart von Post (1884-1951; Figs. 1, 2) was state geologist in Uppsala and latterly Professor of Geology in Stockholm (Manten 1967). He is credited with formalising the pollen-analytical method, but he cannot be said to have formulated it. This is most consistently stated to have been his mentor, Nils Gustaf Lagerheim (1860-1926; Fig. 2), Professor of Botany in Stockholm, who 'did not publish anything on pollen analysis' but was its 'spiritual father' (Erdtman 1943, p. 5). Lagerheim's pollen counts were incorporated in a monograph by Nils Olof Holst (1846-1918; Holst 1909, p. 30) of the Swedish Geological Survey where we are told (translation from Erdtman 1943, pp. 4-5):

...a reliable method with which to follow, step by step, from one layer to another the immigration of all plants whose pollen or spores are preserved as well as the relative frequency of these species. When the rate of formation of all the different layers can be determined, it will also be possible to calculate the speed with which the plants in question immigrated.

This would seem to be the basis of translations and paraphrases which also appear in von Post (1918, p. 440; translation von Post 1967, p. 383), Selling (1951, p. 280), Manten (1967, pp. 17-18) and Mitchell (1984, p. 25). It is not a great stretch of the imagination to see that the foregoing

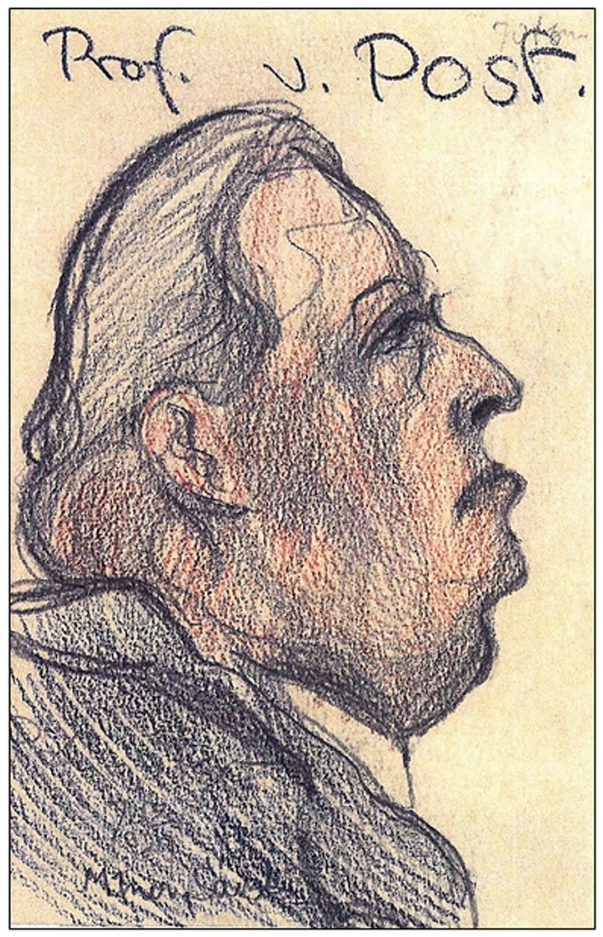

Fig. 1 Drawing of Lennart von Post by Carl Benedicks, Center for History of Sciences, The Royal Swedish Academy of Sciences

quotation is probably also the origin of von Post's (1946) later unsourced comment (pp. 196-197) that:

...by examining statistically a series of beds, layer by layer, the fossil pollen rain, which composes the "pollen floras" or "pollen spectra", of the respective layers, we can follow from period to period the changes in the woodland geography of the region.

The statement in Holst (1909) is perhaps the key proclamation for pollen methodology. Manten (1967, pp. 17-18) is ambiguous as to whether the suggestion came from Lagerheim or Holst, though the original Host text seems clear-'såsom LAGERHEIM själf framhåller' ('as LAGERHEIM himself emphasizes') (Holst 1909, p. 30). Holst had approached Lagerheim to carry out pollen studies and it was also Holst who advanced ideas on the migration of Picea and on the value of pollen as opposed to plant macrofossils alone. The end pages of Erdtman's (1943) An introduction to pollen analysis contain portraits of Holst as well as Lagerheim and von Post (1946, pp. 231, 233, 235). It might be noted that Erdtman (1943, pp. 6-7) devoted five paragraphs to the 1905 thesis of German natural scientist Ulrich Steusloff (1883-1953; Schlickum 1953), while Selling's (1951) obituary of von Post also recorded that Steusloff had been on the same track as Lagerheim without further development of the idea ('varit inne på samma banor utan att I huvudfrågan komma längre'; p. 280). 
Fig. 2 Pictures of some of the early palynologists discussed in this paper. Sources: Lagerheim-Svenskt Biografiskt Lexicon; von Post-Geological Survey of Sweden; ErdtmanJonsell (2007); WoodheadKirklees Museums and Galleries; Raistrick-Alan Butterfield; Blackburn-Smithsonian Institution Archives; Kertland—drawing by Raymond Piper, Linton (1977); GodwinF.T.N. Elborn, Department of Plant Sciences, University of Cambridge; Fraser-University of Aberdeen (Cameron 2007); Hyde-Amgueddfa Cymru National Museum Wales; Jessen - public domain; MitchellPeter Coxon
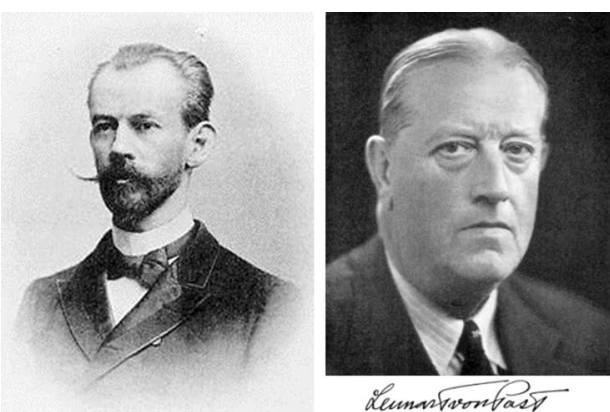

wrontast
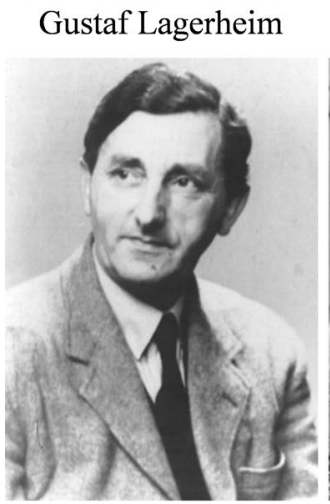

Arthur Raistrick

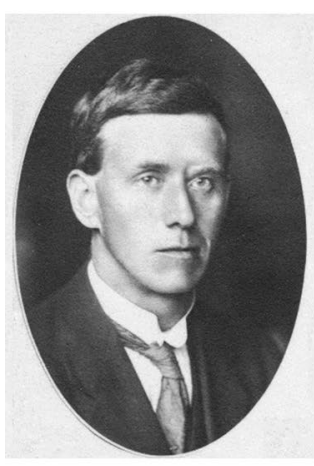

George Fraser
Lennart von Post

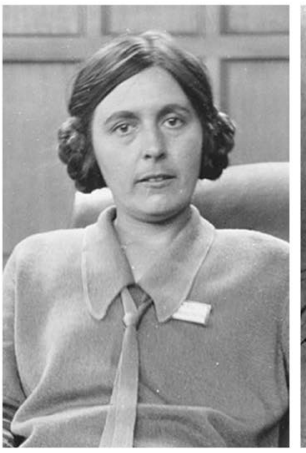

Kathleen Blackburn

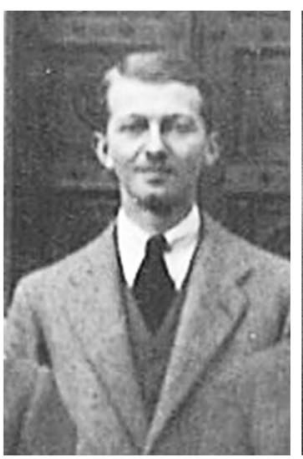

Harold Hyde

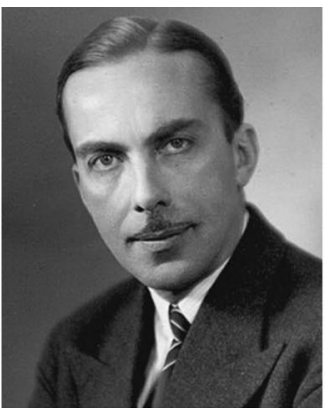

Gunnar Erdtman

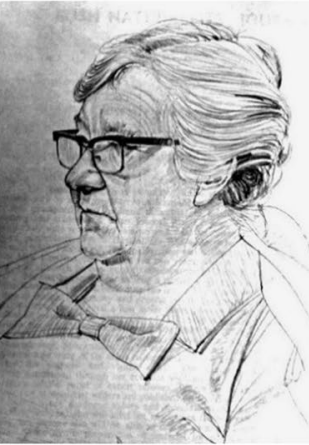

Mary Kertland

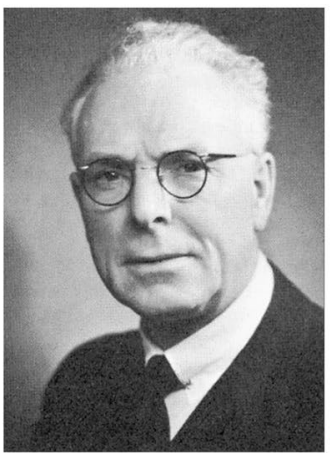

Knud Jessen

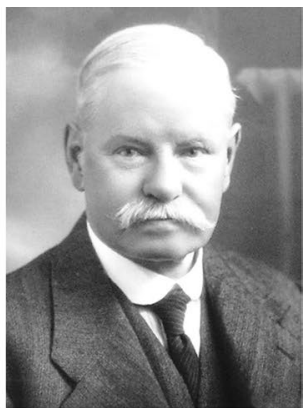

Thomas Woodhead

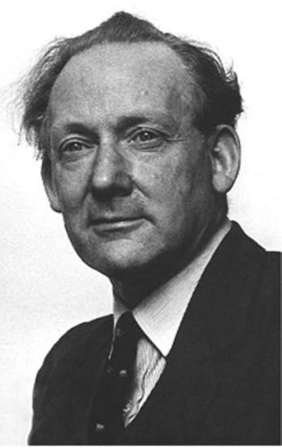

Harry Godwin

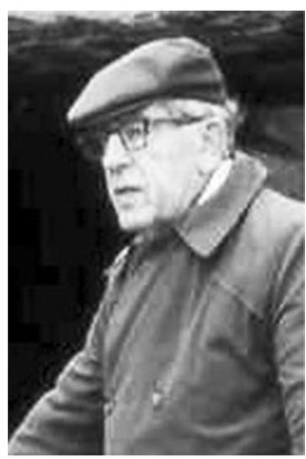

Frank Mitchell
Even though there were many forebears (cf Erdtman 1943; Fægri and Iversen 1950; Manten 1966), what is clear is that von Post pioneered the use of the pollen diagram and was responsible for much besides. This is simply shown by a perusal of the topics which he addressed in his 1918 paper as well as in his Vega Medal Lecture to the Swedish Society for Anthropology and Geography (von Post 1944, 1946) (Table 1). These contributions represent factual, methodological and conceptual milestones in the discipline.

The first pollen diagrams were produced in another 1916 article (von Post 1916b; Nordlund 2014). It was Fries (1967), however, who presented a monochrome photograph showing von Post's original wall-chart which had consisted of a series of hand-coloured, selected taxa curves from a transect of peat bog sites stretching from Denmark in the south to the northern oak border in southcentral Sweden. The supposed Grenzhorizont (Weber
1900) formed a synchronous datum. It is surprising that von Post's innovative graphical concept was not published in his paper-was it too novel, or, as communicated to John Birks by Knut Fægri, was it too big to reproduce in 1918 (Birks 2017, pers. comm.)? In any case, a variant of it appeared a decade later (von Post 1926), where the Danish site was omitted, but including curves for Carpinus and the mixed oak forest (Quercus, Tilia and Ulmus).

There is a further ingredient in von Post's repertoire which is worthy of comment, and that is his use of mapped data. Those published by him for southern Sweden in 1924 show a comprehensive concern with tree and shrub communities and their spatial and chronological dispositions which would not be out of place today. His proportional circles and pie-charts adorn no fewer than eight maps which span a time period from the present [his Fig. 6 shows apparent surface samples (recenta prov; in contrast to subrecenta samples 
Table 1 Selected themes explored by von Post in his publications dating to 1918 and 1944

\begin{tabular}{|c|c|c|}
\hline Themes & 1918 & 1944 \\
\hline Earlier workers-Lagerheim, Weber, Früh & $X$ & \\
\hline Dating_Grenzhorizon, Blytt-Sernander, archaeology & $X$ & \\
\hline Macrofossils insufficient—allochthonous components & $\mathrm{X}$ & \\
\hline Absence of evidence not definitive—-beech, yew & $\mathrm{X}$ & \\
\hline Sample taphonomy & $\mathrm{X}$ & \\
\hline Genus not species of taxa & $X$ & \\
\hline Pollen preservation & $\mathrm{X}$ & \\
\hline Counting statistics—size, sample thickness, $\%$, absolute & $\mathrm{X}$ & \\
\hline Pollen diagrams & $\mathrm{X}$ & \\
\hline Spatial coverage & $\mathrm{X}$ & \\
\hline Multiple core-on-site, off-site & $\mathrm{X}$ & \\
\hline Long distance transport & $X$ & \\
\hline Differential migration of woodland & $X$ & \\
\hline Empirical/rational limits of palynological data & $\mathrm{X}$ & \\
\hline Optimization of rare types & $X$ & \\
\hline Isotherms and pollen presence & $\mathrm{X}$ & \\
\hline History of climate, including Milankovitch & & $\mathrm{X}$ \\
\hline Soil exhaustion & & $\mathrm{X}$ \\
\hline Model situations & & $\mathrm{X}$ \\
\hline General laws_regional parallelism & & $\mathrm{X}$ \\
\hline $\begin{array}{l}\text { Global patterns-though must look at data indepen- } \\
\text { dently first }\end{array}$ & & $X$ \\
\hline
\end{tabular}

$5 \mathrm{~cm}$ below the surface; von Post 1918, p. 451)] back to Boreal times; these display a level of detail which was not always surpassed in later exercises.

\section{A geological/botanical dichotomy?}

Influenced by the likes of Norwegian botanist and geologist Axel Gudbrand Blytt (1843-1898; Oslo), Swedish botanist, geologist and archaeologist Johan Rutger Sernander (1866-1944; Uppsala), and mediated via Lagerheim, von Post saw the stratigraphical importance of pollen within peat and other deposits. The pollen spectra though were essentially to be seen as reflecting changing microfossil assemblages (which have an ecological significance), but not necessarily correlative with either plant macrofossils or peat stratigraphy (cf von Post 1967, pp. 380 and 401).

In spite of this, there is a perspective that von Post's approach to pollen analysis was constrained because it was geological and stratigraphic rather than botanical or ecological. Thus:

Although limited by being a geologist, he fully saw that the future development of pollen analysis had to be thought in the refined morphological and, even more so, the ecological problems of which he him- self did not possess a sufficient command (Fægri and Iversen 1967, p. 377).

...although he was not a botanist, [he showed] the possibility of throwing valuable, perhaps piloting light upon plant interrelationships by detailed studies of their pollen grains and spores (Erdtman 1967, p. 26).

The impression may have been strengthened by von Post himself, who, inter alia, regarded his new science as prospectively geological in a chronological sense:

Pollen analysis in its present form, or, as it should be properly called, pollen statistics, since the fundamental principle of the method is quantitative, was designed mainly to serve as a means of determining geological time. (von Post 1946, p. 196)

This, however, is to ignore the ecological perspectives which pervade von Post's papers (cf Table 1). Apart from palynological contributions themselves, he also published phytosociological studies of the Skagershult peat bog (von Post 1910) in which the first ever Swedish maps of mire vegetation were 'internationally among the first detailed studies of this kind' (Manten 1967, p. 17).

In the context of the period in which von Post received his training, the natural sciences of geology, botany and zoology were frequently studied together; we have already seen the multidisciplinary backgrounds of Blytt and Sernander. Von Post had intended to study zoology at Uppsala, but he came under the influence of Arvid Gustaf Högbom (1857-1940), a geologist, and the botanist Lagerheim, as well as having personal contact with Sernander. He specifically mentions (von Post 1946, p. 213) the palaeobotanist Albert Charles Seward (1863-1941) whose influential multi-volume Fossil plants was sub-titled A text-book for students of botany and geology (Seward 1898-1919). Even the 'botanist' Erdtman (1967, p. 24) 'joined forces with Lennart von Post in the summer of 1918. I had been accepted as his assistant among about a dozen other young botanists and geologists'. Fægri (1973, p. 6) may have considered the student to have become the new botanical 'Mr. Pollen Analysis...the Grand Master', but the student clearly had no qualms mixing it with geologists and botanists, nor with lauding both in his publications. It is also worth noting that Knut Fægri and Johannes Iversen, both botanists, dedicated the first edition (1950) of their seminal Text-book of modern pollen analysis to Lennart von Post, 'the grand old man of pollen analysis'.

\section{Britain, Ireland, Scandinavian connections, Gunnar Erdtman and antecedents}

Great Britain had a long palaeobotanical tradition and this was open to Scandinavian palynological influences at an early stage. In a Quaternary environmental context, the first 
British notice of pollen may have been that of palaeobotanists Clement Reid (1853-1916) and his wife Eleanor Mary Reid (née Wynne Edwards; 1860-1953) who found groups of stamens with well-preserved pollen grains in dredged 'moorlog' from the North Sea's Dogger Bank (Reid and Reid 1909) which they subsequently identified as 'willowherb' (Reid 1913, p. 45). Further work on the site by the Reids recorded pine pollen (Goodchild 1920) and as will be shown, the site received later Swedish attention.

The first paper to report pollen from mainland sites in Britain was that of Stockholm botanist Gunnar Samuelsson (1885-1944) who presented qualitative pollen data from the English Pennines, and the Southern Uplands, Grampians and northwest Highlands of Scotland (Samuelsson 1910). The pollen analyses were produced by Gustaf Lagerheim, although the paper is primarily concerned with the development of peat stratigraphy and comparisons with the Scandinavian efforts of Blytt, Sernander and others. The mode of reporting barely goes beyond such configurations as 'Lagerheim has found pollen grains of birch, hazel, pine, and probably Empetrum' (Samuelsson 1910, p. 202).

Similarly terse reports of pollen finds are available. Marjorie Elizabeth Jane Chandler (1897-1983), a Cambridge palaeobotanist, was a long-time research associate of Eleanor Reid after the death of Clement Reid. She found undeveloped pollen grains of Armeria arctica in a calyx retrieved from Lateglacial deposits at Barnwell (Chandler 1921).

By 1922, the work of Otto Gunnar Elias Erdtman (1897-1973; Fig. 2) was coming to the attention of a British audience. London ecologist Edward James Salisbury (1886-1978) cited the Swede's (Erdtman 1921) 'extensive and fascinating paper' (Salisbury 1922, p. 554), which was in fact a monograph and doctoral thesis, and not actually Erdtman's first pollen-analytical paper (Erdtman 1920). He had rapidly obtained his suite of degrees at Stockholm, culminating in his fil. Dr. by the age of 25 , reputedly the then youngest recipient of a doctorate in Sweden (Edlund and Winthrop 2014). By writing in a world language-German and more usually English-he, and the science of pollen analysis, became well known internationally.

Erdtman visited Britain and Ireland during the 1920s. His short paper (1923) on northern Scotland was, in fact in Swedish (with a French abstract) and contained no pollen diagrams. This was followed by a substantial English language version in a British journal (Erdtman 1924a), with 18 rudimentary, low resolution pollen diagrams showing only arboreal taxa. Even at this stage comparisons are made with data from other parts of Europe, presaging Erdtman's interest in broad-scale generalisations as would be seen in his 1931 contribution to the history of hazel forests (Erdtman 1931). His 1924 article (Erdtman 1924a) was communicated to the Linnean Society by Edward Salisbury and offers thanks to Eleanor Reid for correcting the English. With the Scottish paper in press, he published a German language article in the same year with three tree pollen profiles from Ireland (Erdtman 1924b), a paper on the Isle of Man (Erdtman 1925), and his first paper on an Irish topic written in English (Erdtman 1927, which included a single diagram from Co. Mayo which had been published previously in 1926).

The first paper by a Briton involving more than an observation on the existence of pollen grains seems to be that of William Holmes Burrell (1864-1945), retired Norwich pharmacist, a noted bryologist and honorary curator of the herbarium at the University of Leeds. Burrell had for some time been conducting work on Pennine peats along with others (Woodhead 1924; Kosanke and Cross 1995). His only paper on the topic containing palynological observations appeared in 1924. There he acknowledged an 8-year cooperation with the naturalist Christopher Arthington Cheetham (1875-1954), who supplied the fine photographs of 'Peat Organisms' (including an unrecognised pollen grain which is clearly Tilia). His summary of results [with 'micro examination of peat samples, after treatment by the alkali process detailed by Mrs E. M. Reid, B.Sc.' (Burrell 1924, p. 147)] included Betula and Corylus pollen, both 'indistinguishable' from each other, Pinus, and spores of Polypodium and Sphagnum. The pollen evidence suggested to him that the Pennines were formerly scrub-covered and that sufficient woodland remained in appropriate habitats to supply the wind-blown pollen after trees had ceased to grow locally. He noted the work on peat in the Geology Department at Leeds by 'Miss Elsie Whitaker, M.Sc...[who] obtained new evidence of pine, birch and hazel beneath the peat; it is regrettable that her thesis has not been made available by publication' (Burrell 1924, p. 146). It is unclear from this whether the research of Elsie Dinah Whitaker (1895-1985; Mrs Harry Ward) featured pollen [though Woodhead and Erdtman (1926) say that she did] and her thesis has not proved traceable. Burrell also hosted a young WisconsinMadison botany/geology student for his junior year (Cross and Kosanke 1995; Kosanke and Cross 1995). Suitably inspired by Burrell, who had himself been galvanized after a visit to Leeds by Erdtman, the trans-Atlantic visitor, Leonard Richard Wilson (1906-1998), went on to become a pioneering and distinguished palynologist at the University of Oklahoma.

Thomas William Woodhead (1863-1940; Fig. 2) has been lauded as a pioneer whose energy, encouragement and influence in the worlds of ecology, pollen analysis and museum development were remarkable (Pearsall 1940; Salisbury 1964; Sheail 1988; West 2014). Starting employment as a woollens salesman, Woodhead took a reduction in salary to become a lecturer in biology at Huddersfield Technical College in Yorkshire, from which he was able to undertake spells of research leave in Bonn, Leeds, London and 
Cambridge. He was even offered a post in the Botany School at Cambridge by its then head, Harry Marshall Ward, but 'felt unable to take up the life' without a private income (Sheail 1988, p. 126). Huddersfield further granted leave of absence to undertake study for a doctorate, and on Marshall Ward's advice he pursued his ecological interests with geobotanist Karl Joseph Schröter (1855-1939) in Zurich, being awarded a $\mathrm{PhD}$ in a year for a thesis on the 'Ecology of woodland plants in the neighbourhood of Huddersfield' (Woodhead 1906). In a congratulatory letter, Louis Compton Miall (1842-1921), Professor of Biology at the University of Leeds, described the research as 'a capital piece of work. It is very encouraging to see the sterile publications of our Yorkshire naturalists are being replaced by investigations of a truly scientific character' (22 November 1906, Woodhead papers). A further letter of congratulation was received from William Gardner Smith (1866-1928) with whom Woodhead, along with Charles Edward Moss (1870-1930) and Arthur George Tansley (1871-1955) had formed the Committee for the Survey and Study of British Vegetation in 1904, which was eventually to become the world's first ecological society, the British Ecological Society, founded in 1913 (Sheail 1987). Delivering the Society's Presidential Address in 1927 on the history of vegetation in the southern Pennines, in a paper which, in its multi- and inter-disciplinarity and insights has been described as 'a landmark in the history of the subject' (West 2014, p. 23), Woodhead (1929, p. 17) anticipated that despite methodological uncertainties, 'pollen-statistics' would 'yield results of great importance'.

Erdtman stayed with Woodhead in Huddersfield prior to October 1925 (Cheetham 1925). The paper they published together (Woodhead and Erdtman 1926) is significant because it represents the first paper, with a British author, to feature pollen diagrams - though it is quite clear that this is the work of the Swede-while also representing the first paper which combines archaeological and pollen data. The minerogenic and peat deposits at the site (Warcock Hill, near Huddersfield), spanned the Mesolithic and later periods, and permitted the human story of the south Pennines to be placed within a more secure and wider environmental context.

An unknown issue is the extent to which Woodhead himself analysed pollen. Sheail (1988, p. 126) relates an unsourced quotation saying he turned 'one large bay window and half a dozen bottles' into one of the best equipped biology departments in the country. A letter from Woodhead to Erdtman mentions a sample from Lower Halstow in the Thames Valley and 'We find in it Birch pollen grains' (17 May 1927, Woodhead papers). Another letter sent 14 October 1931 (see below) notes his lack of facilities for this.

Given the formality of correspondence between professionals at this time, it is possible to discern a warmth between Woodhead and Erdtman. Woodhead sometimes addresses the Scandinavian as 'My dear Erdtman', Erdtman thanks Woodman for his assistance with correcting the English of manuscripts, and they both look forward to re-meeting in London. There is a poignancy in a letter to Erdtman sent on 14 October 1931 (Woodhead papers):

When in London recently I was very pleased to hear about you from Prof. Fries...During the past year I have had many difficulties to contend with which have greatly interfered with my work, but I have always had you and your work in mind... several students are now at work on our peat moors...I am in touch with most of these, and if you had the time to help and guide them I am sure some good would come out of their efforts. I have not now the facilities to carry on pollen analyses but I can do something to encourage the younger ones...we need your expert knowledge to see the work is done in a reliable way.

Harry Godwin [Professor Sir Harry Godwin (1901-1985; Fig. 2) and Britain's most influential and energetic Quaternary palaeoecologist of the era], was later to write (Godwin 1981, p. 17) that his interest in acid mires 'was sharply encouraged by a visit to the Cambridge Botany Club of the wise and homely figure of Dr. T. W. Woodhead.... a formidable pioneer ecologist'.

In a letter dated 14 March 1932, Woodhead tells Erdtman that 'Perhaps two of our most active workers on peat are Dr. Raistrick and his colleague, Dr. Blackburn'. Arthur Raistrick (1896-1991; Fig. 2) has been termed 'Britain's premier palynologist' (Marshall 2005) in recognition of his original and pioneering contribution to a discipline which he had abandoned by the start of the Second World War; he was declared 'The Dalesman of the Millennium' thereafter (Brown 2013). Raistrick was a socialist, a Quaker, a pacifist and an apprenticed engineer in Bradford. As a conscientious objector during the First World War, his employment was terminated, he refused conscription and was imprisoned in solitary confinement with hard labour, experiencing bullying and beating. In 1919 he was accepted by Newcastle University and degrees in engineering were followed by a $\mathrm{PhD}$ in glacial geology. Raistrick was lacking in full-time paid employment, but occupied himself with teaching for adult classes, contract work on coal-field geology, and publishing papers on glacial geomorphology and prehistoric, historical and industrial archaeology. At some stage in the 1920s, Raistrick and Woodhead became acquainted and in their joint paper on plant remains in postglacial 'gravels' near Leeds, they record that 'careful microscopic examination of the material failed to reveal any pollen grains' (Raistrick and Woodhead 1930, p. 40), though Burrell identified some mosses and there were many tree remains.

In 1929 Raistrick was invited to apply for a lectureship in applied geology at Newcastle. In addition to ground-breaking research on the palynological correlation of coal-seams 
(Raistrick and Simpson 1933; Raistrick 1938), he began working with Kathleen Bever Blackburn (1892-1968; Fig. 2), primarily a cytologist, of the botany department (Valentine 1970; Hart 2017). Blackburn had acquired a knowledge of pollen analysis by visiting von Post in Sweden (Lunn 1983); this was 'common knowledge among her colleagues in the Botany Department of what was then King's College, Newcastle' (Angus Lunn 2017, pers. comm.). The Blackburn-Raistrick collaboration resulted in a series of papers on the Pennines and the English Lake District (e.g. Raistrick and Blackburn 1931, 1932, 1933) — part of a plan to produce pollen profiles on a 10-mile grid (Raistrick 1932; Marshall 2005); 'Such a scheme provides room for co-operation of local workers' (Raistrick 1932, p. 181). In their 1932 paper, Raistrick and Blackburn thank Woodhead and Erdtman for their 'constant interest and suggestions' and Harry Godwin 'for assistance in the field' (Raistrick and Blackburn 1932, p. 102; cf; Fisher 1975). Godwin himself makes no reference to this early involvement (Godwin 1981, 1985).

As a pacifist, Raistrick refused to register for army teaching or research work during the Second World War (at the age of 43 at the outbreak of war he was 2 years beyond the age of conscription) and he was partly ostracized socially. He did some informal teaching, published magazine articles on past and present life in the Yorkshire Dales and wrote the popular Teach Yourself Geology (Raistrick 1943). After the war, and especially in retirement, he became heavily involved with the National Parks Movement and the Youth Hostel Association. In 1974, at the instigation of the Prime Minister Harold Wilson, Raistrick was offered the Order of the British Empire (O.B.E.). This he declined with some eloquence (DNB 2004):

As a lifelong member of the Independent Labour Party I have frequently spoken against the system of the honours list. I feel that I cannot at this time break my principles and accept the prime minister's suggestion. My thanks for the thought so expressed are no less sincere and I shall value this gesture more than I could value the honour itself.

We do not know who produced the pollen data reported by Burrell (1924)—whether him, Cheetham or Whitakerbut, in 1926, the year that Woodhead was publishing pollen data and diagrams with and by Erdtman, another Briton was publishing self-generated pollen data. Charles Beard Travis (1878-1949), a clerk and local stalwart of the Liverpool Geological Society, was in communication with Ertdtman and presented pollen from coastal peat beds in Lancashire for which 'I am alone responsible' (Travis 1926, p. 267). Owing to a lack of variation in the spectra, 'I have not thought it necessary to construct any diagrams showing graphically the composition of the pollen-flora' (Travis 1926, p. 269). Percentages for tree pollen were presented along with presence/absence data for some herbs and cryptogam spores. This approach bears strong similarities to one of Travis's later articles (1929).

Research involving palynology in the Department of Botany of The Queen's University of Belfast was fostered by James Small (1889-1955), Professor of Botany, who communicated with Erdtman in 1926 and 1927. It seems likely that the first paper to feature pollen diagrams derived from their own data from these islands was produced by Mary Patricia Happer Kertland (1902-1991; Fig. 2), doyen of the Belfast Naturalists' Field Club and curator of the herbarium at Queen's (Linton 1992). Kertland (1928) presented pollen data from the summit of Divis, close to Belfast. Interestingly, Small had submitted two duplicate samples to Erdtman from Divis, on Kertland's behalf, producing similar results. The diagram contained only a restricted range of tree and shrub taxa, but she made useful, albeit limited observations on the sources of the pollen. The latter topic also applies to the paper by J. I. Armstrong, J. Calvert and Cecil Terence Ingold (1905-2010; he went on to become a distinguished mycologist) on the ecology of the Mountains of Mourne (Armstrong et al. 1930). This trio of Queen's botanists presented concentration as well as relative data (though no pollen diagram), and inferred that the tree pollen had been transported to the site by wind-'It appears to us that for the reconstruction of the old tree line in a mountain region only evidence based on wood embedded in the peat is of any value' (p. 451). A further Queen's botanist was Jean (Jeanne) Margaret White (born 1919 in Co. Leitrim) who also presented concentration and relative pollen data (including a percentage diagram) associated with a Neolithic skeleton embedded in peat in Co. Galway (White 1931).

Margaret Elizabeth Godwin (née Daniels; 1898-1989) was encouraged to undertake pollen-analytical research by Arthur Tansley (the latter was then Professor of Botany at Oxford having previously studied psychology in Vienna with Sigmund Freud after a period as lecturer in botany in London and Cambridge). This fortuitous suggestion, partly a result of Tansley's awareness of Erdtman's research (Godwin 1985, p. 155), was to have far-reaching consequences. Margaret Godwin's forays into palynology were always published with husband Harry (e.g. Godwin and Godwin 1933a, 1940), who had become her research collaborator. Kathleen Blackburn is thanked 'for her helpful advice on the technique of pollen analysis' in one of their early papers (Godwin and Godwin 1933b, p. 180).

The Godwins' adoption of the technique, and its energetic expansion from the Botany School at Cambridge, was to be helped by the formation of The Fenland Research Committee in 1932 (with Seward as President, prehistorian Grahame Clark as Secretary and the Godwins as palaeobotanists). It represented a turning-point in environmentally-informed archaeology (Smith 1997), as did the subsequent creation in 
Cambridge of the Sub-department of Quaternary Research under the direction of the Departments of Botany, Geology and Archaeology (and later Geography) in 1948 (Godwin 1981; Edwards 1986a; West 2014).

Likewise, the field received a major boost in the Republic of Ireland after the formation of The Committee for Quaternary Research in Ireland (Praeger et al. 1934). The Committee noted Erdtman's visits to Ireland in 1922 and 1926; indeed several members had corresponded with the Swedenatural historian Robert Lloyd Praeger, geologists John Kaye Charlesworth and Timothy Hallissy, and archaeologists Claude Blake Whelan and Adolf Mahr. On the recommendation of Norwegian botanist Rolf Nordhagen, Knud Jessen (1884-1971; Fig. 2), Professor of Botany at Copenhagen who had been taught to identify pollen by Lagerheim (Troels-Smith 1975), was invited to carry out fieldwork and to train promising students. During field sessions in 1934 and 1935, 'a younger Irish worker was in attendance throughout, for the longest time Mr G. F. MICHELL and for shorter periods Mr T. MAHER and Mr C. J. LA TOUCHE' (Jessen 1949, p. 88). George Francis ('Frank') Mitchell (1912-1997; Fig. 2) accompanied Jessen 'in the dual capacity of courier and brain-picker' (Mitchell 1976, p. 12). He went on to become an internationally known palynologist and Quaternary scientist, establishing Trinity College Dublin's reputation in this field (Mitchell 1940, 1951, 1956, 1990; Watts and West 1999; Watts 2008). Thomas Maher seems not to have published, while La Touche (1936) engaged to the extent of producing a note on Carpinus pollen in Irish peat for Nature. As for Jessen, he published, or contributed to various papers (e.g. Mahr 1934; Jessen 1936; Jessen and Farrington 1938) prior to the appearance of his much delayed treatise on Ireland's Late Quaternary deposits (Jessen 1949).

It is noteworthy that most of the British and Irish workers mentioned thus far exchanged letters with Erdtman (and not to overlook the von Post-Blackburn connection). This is also the case with Birmingham mycologist Charles Geddes Coull Chesters (1904-1993) who was communicating with Erdtman in 1929 and had his identifications checked by the Swede with the results published 2 years later (Chesters 1931).

Harold Augustus Hyde (1892-1973; Harrison 1974; Fig. 2), Keeper of Botany at the National Museum of Wales, Cardiff, kept up a long correspondence with Harry Godwin and an occasional one with Erdtman, but seems to have been largely self-taught in pollen analysis, having graduated from Cambridge before the Second World War. His first paper involving pollen analysis appeared in 1936 in which he acknowledges Blackburn and Godwin for advice on methods (Hyde 1936). He worked with Godwin and Frank Mitchell at Tregaron Bog, along with Blackburn (Godwin and Mitchell 1938, p. 426). He was joint originator of the word palynology (Hyde and Williams 1944) and he turned fulltime to aeropalynology after retirement (Hyde and Adams 1958).

A link to Scotland relates to perhaps the first ever Chinese palynologist. Su Ting (1913-2000) was corresponding with Erdtman from the beginning of 1935 . His pollen work on the Isle of Bute is contained in an appendix to his $\mathrm{PhD}$ thesis which was the first by a Chinese national at the University of Glasgow (Ting 1937). He was to later publish a paper on Chinese pollen (Ting 1949) and to become Professor of Geography at California State University, Los Angeles, where he was known as William S. Ting (e.g. Ting 1965; Edwards and Mao unpublished).

At a discussion meeting of the Royal Society of London in 1935, Godwin had presented data on postglacial floras (Seward et al. 1935). In response, John Baird Simpson (1894-1960) of the Geological Survey of Scotland reported that he had carried out pollen analyses of a submerged forest-bed beneath a raised beach peat from Bridge of Earn, Perthshire, and the results agreed with those of Erdtman from a similar context, but different locality. More importantly, he questioned the contemporaneity of vegetational changes 'if the zones have merely followed up the ice-retreat...in widely separated north and south localities in Britain' (Seward et al. 1935, p. 232), thus anticipating later considerations of time-trangressiveness (e.g. Smith and Pilcher 1973). Simpson also worked on pre-Quaternary pollen floras (Simpson 1934, 1961).

An exception to the 'Erdtman connection' is George Knowles Fraser (born 1891 in Aberdeenshire; Fig. 2) who obtained the first degree in forestry at the University of Aberdeen in 1919. Fraser went on to lecture in the subject at the University, joining ecologist Alexander Stuart Watt (later of Cambridge), before moving to the Macaulay Institute for Soil Research. His study on moorlands and peat growth (Fraser 1933) 'remains the basis for classification of peat covered land types in Scottish forestry' (Wood 1974, p. 17). Of greater relevance here is that he trained with von Post in 1936-indeed, a portion of his Aberdeenshire Strichen Moss diagram represented Scotland in von Post's Vega Lecture paper (1946, p. 202). The same site first appeared as an unnamed pollen profile (his Fig. 4) in Part I of a 'Wartime Pamphlet' (Fraser 1943), although it was most usefully published along with a site from western Scotland after his death (Fraser and Godwin 1955). Fraser, with Blackburn, would appear to be the only British researcher to have worked in von Post's laboratory.

In 1932 and 1933, Mrs Florence Nellie Campbell James (née Vobes; 1880-1934) had conducted pollenanalytical and stratigraphic investigations associated with the submerged forests of Cardigan Bay. Unfortunately she died before submitting her thesis to the Department 
of Botany at Aberystwyth, and a paper on her work was published by Harry Godwin and Lily Newton (née Batten; 1893-1981) in 1938 (Godwin and Newton 1938). There are a number of additional workers who seem to have produced no more than one pollen-related contribution in this early period. This is so for a trio of papers on Welsh sites. Norman Woodhead [1903-1978; with a curiosity in ley lines (Stout 2009)] and L. M. Hodgson (Woodhead and Hodgson 1935; see also; Hodgson 1933) of Bangor presented data from 17 peat sites in Snowdonia, including coarsely-sampled arboreal pollen profiles. Of interest was their consideration of statistical sampling errors, tree-line altitudes, climate change and the absence of archaeological dating material. In 1945, E. G. Davies (Botany, Aberystwyth) produced an ecological, erosional and stratigraphic study of an upland bog in Cardiganshire under the supervision of Lily Newton (and part of a larger scheme of work "which of necessity has been temporarily postponed' (Davies 1945, p. 166) presumably as a result of the War). This contained otherwise unpublished pollen profiles by Dr J. B. Jones of the same Department.

In 1939, Arthur Roy Clapham (1904-1990), then an Oxford botanist and originator of the word 'ecosystem' as suggested to Tansley (Willis 1997), produced a paper on a valley fen in Berkshire with his wife Brenda North Clapham (née Stoessiger; 1903-1985) (Clapham and Clapham 1939). Brenda was originally a statistician (a student of Karl Pearson) and their initials appear jointly on the site's pollen diagram, while Godwin is thanked for advice. Also in 1939, E. M. Hardy (Cambridge) published a study of Shropshire mosses, and a year later, H. C. Bibby (1940) of Chesterfield Grammar School, looked at inter-tidal peats, the orientation of associated tree trunks and the pollen content (Godwin is thanked, with others, for advice).

\section{Women in British palynology prior to the end of World War II}

It is well recognised that women, in retrospect at least, can appear to be barely visible in the world of science (Fara 2004; Shetterly 2016). This has not afflicted palynology in quite the same way (cf Hart 2007, although the article contains inaccuracies). Lennart von Post's second wife Selma Therese Constance (Tofsy) Guldbrand (1895-1990) was obviously involved in pollen counting for her husband, but her credits go little beyond acknowledgements in the captions to figures of pollen diagrams (von Post 1924). Within Britain and Ireland, and leaving aside Eleanor Reid and Marjorie Chandler, whose dalliances with pollen were restricted to casual observations of the existence of pollen, and who went on to have distinguished careers in palaeobotany, there are at least 11 women who were involved in palynology up to the termination of the Second World War.

Mention has already been made of Elsie Whitaker, Mary Kertland, Kathleen Blackburn, Jane White, Florence Campbell James, Brenda Clapham and Margaret Godwin. One published female palynologist yet to be cited is Elizabeth May Knox (née Henderson; 1899-1963) of Edinburgh. Although she only appears to have published one paper concerning a Quaternary age site, and that after the war (Knox 1954), she was producing articles on coal-measure spores for many years (e.g. Knox 1938). More central to Quaternary concerns is Winifred Anne Pennington [Mrs T. G. Tutin ('Mrs T'); 1915-2007; Birks and Birks 2007] who 'was hooked on pollen for life' after listening to a lecture by Harry Godwin in 1938 (DNB 2011). Her earliest pollen data took the form of noting the presence of major arboreal types in cores from Windermere (Jenkin et al. 1941; Pennington 1943). Her first substantial contribution to palynology comprised the study of multiple lake sediment profiles (Pennington 1947).

All the above have authorship of papers other than Florence Campbell James and Elsie Whitaker. A further name becomes evident from the archives in a letter from Godwin to Hyde. The latter, involved in atmospheric pollen studies, had mentioned to Godwin 'that Kathleen Blackburn is supposed to be doing a pollen atlas; we do not want to cut in or duplicate her work' (letter dated 9 December 1941, Hyde papers). Godwin replied (letter dated 12 December 1941):

About Miss Blackburn; along with many other jobs she has had the pollen atlas on the stocks for many years. I think like the rest it will be still-born and if I were you I should ignore it...The wife of P. W. Richards (who works here) for some time did pollen work related to airborne pollen in the Fenland but never published it. She may possibly get it together sometime so as to be of use to you.

This refers to Sarah Anne Richards (née Hotham; 1910-2007) who married Paul Westmacott Richards in 1935, a tropical rainforest ecologist who went on to become Professor of Botany in Bangor, and who dipped into palaeoecology himself (Godwin and Richards 1946). In addition there is Hilda Marion Parkes (1916-1992; Mitchell and Scannell 1995), originally trained as a geographer, who counted pollen for Frank Mitchell between 1945 and the early 1950s. Although praised by Michell (1951), no pollen papers seem to bear her name for the period considered in this section. Later, there was a palynological appendix related to an excavation (Parkes and Bradshaw 1988), a posthumous article based on her uncompleted $\mathrm{PhD}$ thesis (Parkes and Mitchell 2000), and she did publish other items (e.g. Mitchell and Parkes 1949; Parkes 1975). 
If invisibility is defined as absence of authorship, then most of the aforementioned do not qualify. If it is a relative observation, for instance in terms of less published output than males, then that may be the case although a comprehensive analysis of this would need to consider career options and choices. There is no question, however, that at various times, but arguably beyond palynology, anti-feminist resentment has been strongly apparent (Boney 1995; Köbl-Ebert and Turner 2016).

\section{Wartime}

The Swede von Post had delivered his seminal lecture in Oslo in 1916, the middle of the First World War. Sweden and Norway were both officially neutral during the conflict. Erdtman (1967, p. 24) reminisced that he had 'joined forces with Lennart von Post in the summer of 1918...in order to take part in a survey aiming at the calculation of the amount and value of the peat deposits in southern Sweden. The survey was made because it was war'.

Globally, academic productivity related to the discipline gradually increased until the outbreak of the Second World War when it seems to have undergone a sharp decline (Manten 1970). For the main protagonists, as well as those countries that remained neutral or were occupied, it is perhaps instructive to consider the fate of their scientific output. Figure 3 shows numbers of publications primarily for Quaternary palynology in a range of countries for the period 1930-1955. The data have not been normalised, but even allowing for the differences in relative productivity between countries and assuming that papers published in 1940 may have been accepted before the start of hostilities in 1939, there are clear falls in output in Sweden, Russia and the United Kingdom. There is variability in The Netherlands but a decline when compared to pre- and post-war levels. France experienced an initial fall, although an increase as the war continued. The levels of output for Norway, Denmark and Finland (other than for 1945) hold up well. Germany's production of papers declines markedly from 1943. In the USA there was an increase through most of the war years and a sharp drop only in 1945 .

None of the above really highlights the suffering and difficulties of individuals. We have already seen how two world wars affected the life of Arthur Raistrick. At a more trivial level, work clearly continued in many institutions throughout much of the Second World War. Godwin, who was too old for conscription at the outset of war, wrote to Hyde: 'Though there is some dislocation, Cambridge is fairly undisturbed still. I feel my field-work may suffer seriously from lack of transport before long' (28 December 1939, Hyde papers). In his tribute to Johannes Iversen (1904-1971), Godwin (1973, p. 1,245) said:
I recall vividly the thrill with which I received clandestinely through Sweden, in the dark days of the war, his monumental paper 'Land occupation in Denmark's Stone Age' (Iversen 1941), and remember how it dramatically confirmed my own tentative hypotheses on the origins of the East Anglian 'Breckland'.

This is reminiscent of some Continental geographers who experienced 'a seeming normality... an accommodation to the circumstances of war' (Withers 2015, p. 91). At the same time, Godwin (1973) wrote of Dane Knud Jessen 'turning their facilities to advantage in resistance to war-time occupation' (p. 1,248).

The Polish palynologist Władysław Szafer (1886-1970) had an eventful wartime and post-War/Cold War history (Szafer 2017). As an officer in the Polish Legion and following a refusal to take an oath to the Emperor of Austria Franz Josef I in 1914, he was demoted and conscripted into the Austrian army. After the Nazis closed the Jagiellonian University in 1939, he served as rector of its clandestine manifestation in Krakow. He was re-instated as Professor of Botany after the war, only to find himself 'an enemy of the system' in the Communist era because of his 'intransigent stance' on Lysenkoism. Today there are public monuments to Szafer in Krakow and Zawoja, many schools and streets bearing his name, and medals in his name awarded to at least two Quaternary palynologists (John Birks, Magdalena Ralska-Jasiewiczowa).

Erdtman, who had continued to maintain extensive letterwriting during the war, 'described schemes to evade postal laws on printed matter, so that...[a] book could be passed through two countries before reaching Sweden, or a precious reprint could be loaned to a colleague' (Edlund and Winthrop 2014, p. 3). Previously he had communicated with Adolf Mahr, Keeper of Antiquities (later Director) in the National Museum of Ireland, concerning archaeological matters and the purchase of a peat corer. There is no evidence that Erdtman was aware that Mahr, an Austrian citizen, was Gruppenleiter of the Dublin branch of the Nazi Party which he had joined in 1933 [he underwent denazification in Germany after the war but was never allowed to return to Ireland (Mullins 2007)]. Jessen did provide a report for a site in Monaghan published by Mahr, although this was instigated by archaeologist Seán O'Ríordáin (Mahr 1934). One of Jessen's two pollen-counting assistants, Hagbard Jonassen ('Jonas'; the other being K.M. Eriksen), a keen pacifist, 'found it difficult not to explode when having to listen to Mahr's fascist tirades' (Mitchell 1990, p. 14).

Perhaps the most bizarre happenstance surrounds the publication of a paper on Cold Fell in the northern Pennines, where the author Joh. Precht (1953, p. 44) tells us that:

It is based on investigations carried out whilst the author was a prisoner of war in the north of England... 
Fig. 3 Numbers of publications ( $y$-axis, note variable scales) in Quaternary palynology appearing within selected countries between 1930 and 1955 (years shown on the $x$-axis of the global data set). The red histogram bars denote the years of World War II (1939-1945).

Data extracted from Erdtman's

'Literature on pollen statistics' series in the journal Geologiska Föreningen i Stockholm Förhandlingar apart from the global data set which is derived from Fig. 2 in Manten (1970)

\section{Sweden}

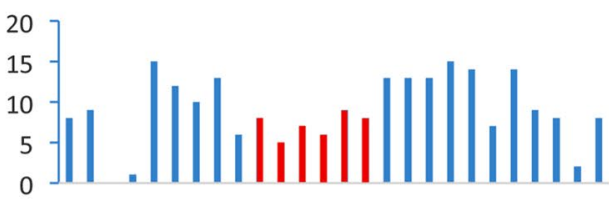

Denmark

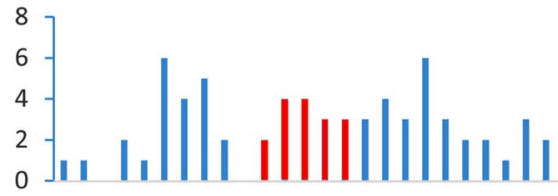

\section{UK}

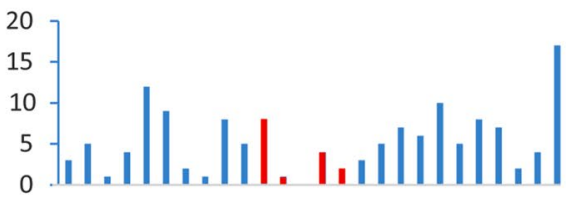

France

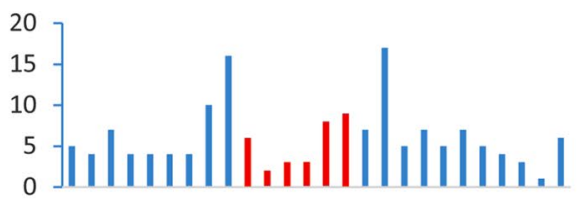

USA

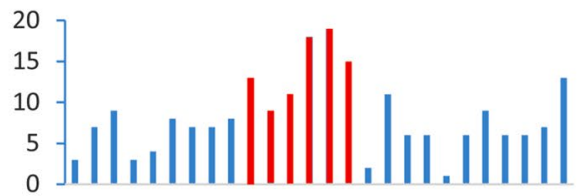

Norway

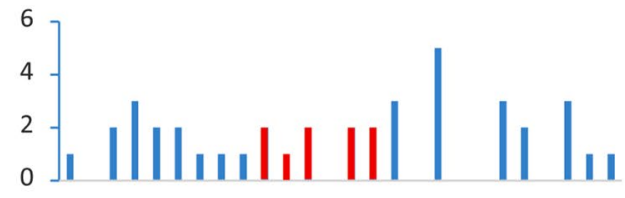

Finland

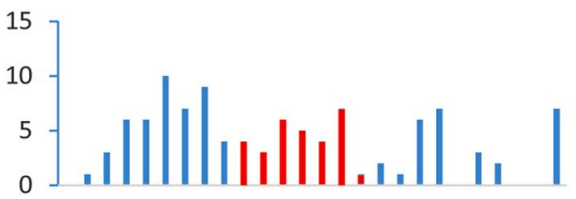

Netherlands

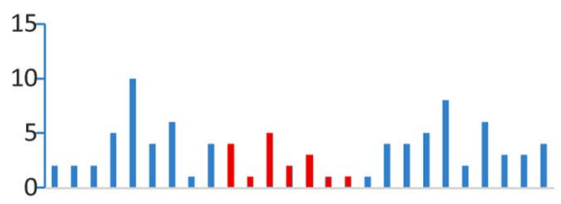

Germany

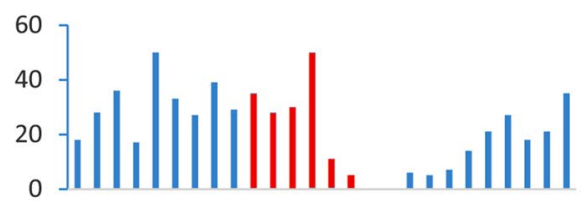

Russia

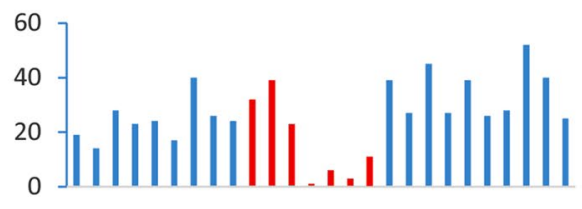

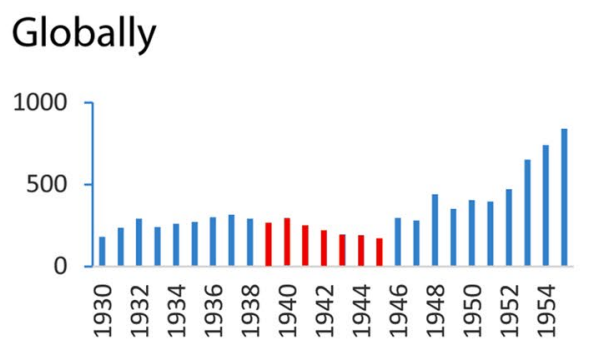

The author would like to express his gratitude to Miss K. B. Blackburn...who always encouraged his work.

The paper had originally been submitted to New Phytologist in German, re-written by Godwin upon receipt of an English version, and finally recommended for a local journal by fellow editor Arthur Clapham (Alan Hart 2017, pers. comm.).
Whatever else these snippets reveal, they demonstrate that palynologists, like all people, did not live in hermetically sealed bubbles.

\section{Biographies, genealogies and influences}

Many ideas and approaches in palynology have had an early and/or long genesis. It is also apparent that today's palynologists are part of an extended disciplinary genealogy that reflects a complicated web of people, influences and 
networks. Discerning the structure of these interrelationships can involve historiography, bibliometrics and oral history. Other fields are well versed in considering their disciplinary legacies (e.g. Simms 1982; Gargiulo et al. 2016), but this is perhaps less so in palynology (Edwards 1983, 1986b) although instances of introspection, tribute, and more formal deliberations are to be found (e.g. Iversen 1954; Haworth and Lund 1984; Mitchell 1990; Edwards 1992; Birks 1993, 2017; Watts 2008; West 2014, 2017; Riding and Dettman 2014; Riding et al. 2016).

Just as family connections and family trees are grist to the mill of genealogists, this can be so for academic subjects. A start to the process for Quaternary palynology might be seen in 'A summary of some of the major interactions and influences within Quaternary pollen analysis in Fennoscandia in the last 50 years' (Fig. 1 in Birks 2005). Birks declares, reasonably, that his paper 'makes no attempt to be exhaustive and inevitably reflects my personal interests and biases' (p. 2). Such constructions are inevitably a question of scale, temporality and compromise, and they are limited by authorial knowledge. The potential complexities are illustrated by Fig. 4 which, for the period up to the end of 1945, presents some of the associations detailed in this paper or which are evident from archives and publications. Although superficially nuanced, it is not possible to be sure that the intricacies of the relationships are accurately portrayed. Indeed, the researchers involved may be unsure about all the relevant influences which may only come into perspective many years after work is published; such insights may only be apparent if autobiographical accounts are produced, as a result of interviews or of historiographical research. In terms of what is depicted in Fig. 4, the position of von Post and Erdtman as 'hubs' is clear. That of von Post stems very much from his catalytic role within the discipline and although, as we have seen, he acknowledges other workers, he may have been less susceptible, or had less need in terms of the nature of his research, to being influenced by them. Erdtman benefitted from publishing in world languages, and being both an assiduous correspondent and a highly motivated scientist. For the United Kingdom, with influence beyond [e.g. doctoral students Joakim Donner (Finland), Vishnu-Mittre (India), Suzanne Duigan (Australia)], Harry Godwin was eventually to inherit this role from Erdtman, and this would have become even more apparent had the timeframe been extended towards the present.

Such research can reveal contradictions or apparent lapses in memory. Erdtman's thesis research was published in Arkiv für Botanik, having been communicated to the journal by Lagerheim and Sernander on 1 June 1921. The thesis was defended in November 1921 with Lagerheim and von Post as opponents. Chapter 3 was called 'Die pollenanalytische Methode nach L. von Post' (Erdtman 1921, p. 15) and Erdtman (1943, p. 5) was later to say that Lagerheim did not object to the title of 'Die pollenanalytische Arbeitsmethode

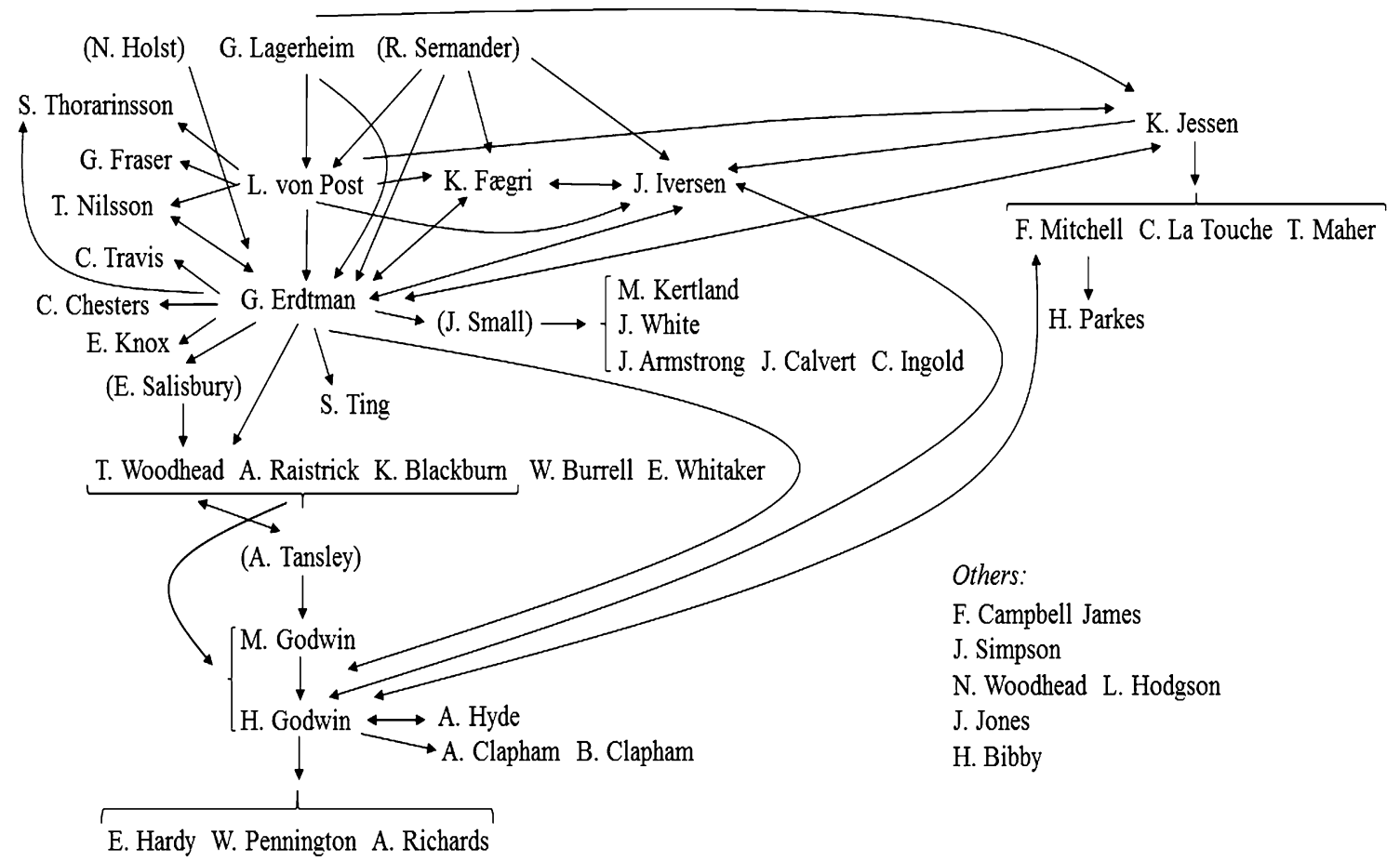

Fig. 4 Interactions and influences between early Scandinavian, British and Irish Quaternary palynologists up to the end of 1945 . Names in parentheses indicate influences rather than individual pollen analysts 
nach L. VON POST' [sic.], although some 18 years later, he (Erdtman) regretted that he did not 'render LAGERHEIM due justice' (Erdtman 1943). In his 1967 retrospective, Erdtman said (p. 25) that the chapter was headed 'The Pollen-analytical method according to Lagerheim and von Post' and that 'Neither of them objected'. Was Erdtman rewriting history in 1967 in order to right a wrong, or simply misremembering?

What such efforts can reveal is the 'colour' and personalities of palynological practitioners, negative, positive or simply interesting. Thus, a notable aspect of von Post's influential papers was his willingness to acknowledge the work of others, especially those who came before him. He was perhaps less charitable when it came to citation of those following him. In his Vega Lecture paper (von Post 1944, 1946), the only mention of Erdtman and that other pollenanalytical giant Johs. Iversen is when both appear hidden in the depths of a substantial caption within the final figure of the article.

There certainly seems to have been a longstanding frostiness between von Post and Erdtman (Fægri 1973, p. 6):

The sad story of two strong personalities who proved to be incompatible. And the academic world being like it is everywhere, Gunnar Erdtman had to be the loser.

After receiving a complimentary letter from von Post concerning his 'pollen bible' (Erdtman 1943), Erdtman sent a letter to his editor Frans Verdoorn (1944, in response to a letter dated 26 January, Erdtman papers):

Godwin, in his review in Nature, was very content with the book, and so is my (previously) bitter and violent antagonist Professor von Post. I am glad that I am able to say that I today received a very friendly letter from him expressing congratulations and unanimous gratitude. All people here, who know the situation between "Erdtman" and "von Post", must say that this means nothing less than a wonder!

Mitchell (1984, p. 26) also comments upon Wodehouse's foreword to Erdtman (1943):

...Erdtman 'standing on the shoulders of his predecessors, has reached into the realms far beyond'. I am sure von Post objected to anyone standing on his shoulders, but he could not abide Erdtman in that position.

One wonders what von Post would have made of the decision of the Palynological Society of India to create the Erdtman International Gold Medal in 1968 (Nilsson et al. 1993)—during Erdtman's lifetime no less?

\section{Conclusions}

Palynology has maintained a foothold in the worlds of environmental science and cultural history and there is a vigorous engagement with such topics as climate change (MacDonald et al. 2008), biodiversity (Gillson 2015), genetics (Parducci et al. 2017), archaeology (Edwards et al. 2015), forensic science (Wiltshire et al. 2015) and health (Burge 2002). At a time when the numbers of palynologists could be in decline (as suggested by the fewer practitioners [Demchuk and Riding 2008] and the fall in the production of dated sites from one area at least [cf.; Grant and Waller 2017]), and given the need to satisfy politically-influenced funders and paymasters, then we may need to be more mindful of the potential socio-economic impact agendas of our research (HEFCE 2017).

This seems a world away from Erdtman's observation that 'If you want to be famous, you should not do pollen analysis, you should do pollen systematics' (McAndrews 1973, p. 9). It is also almost three-quarters of a century since von Post had noted that for many practitioners, routine studies are 'the only goal, and this point of view, that pollen analysis can be an aim in itself, is by no means to be rejected' (von Post 1946, p. 197). Incremental science, of course, can provide the data and give rise to ideas for use in hypothesis-testing and meta-analyses and von Post had also urged the adoption of theory, laws and the scientific method. Anecdotally, it seems clear that many palynologists are unaware of the beginnings and later development of their discipline. Such a knowledge, however, can inform current concerns and provide the necessary data for use in present-day studies and modelling activities.

How safe is von Post's legacy? Well, ignorance of the origins of the discipline represents a loss of heritage. That does not mean that the field collapses, although it may mean that it re-invents things needlessly. Intellectually, it certainly leaves it impoverished.

Acknowledgements I am grateful to the Royal Swedish Academy of Sciences (Kungliga Vetenskapsakademien; KVA), Stockholm, for hosting the conference at which the themes in this paper were presented. For archival material, I appreciate access to (and the assistance of): Gunnar Erdtman papers, Center for History of Science, KVA (Maria Asp); Thomas Woodhead papers, Kirklees Museums and Galleries (Tolson Memorial Museum, Huddersfield; Chris Yates); Harold Hyde papers, Botany Section Correspondence, Amgueddfa Cymru National Museum Wales (Heather Pardoe); Kathleen Blackburn papers, Natural History Society of Northumbria Archive, Great North Museum (Hancock), Newcastle upon Tyne (Alan Hart); material concerning Florence Campbell James, Aberystwyth University (Julie Archer). Richard Bradshaw, Paul Buckland, Andrew Cameron, Peter Coxon, Egill Erlendsson, Michael Grant, Alan Hart, Angus Lunn, Limi Mao, Heather Pardoe, Ed Schofield and Richard West are thanked for advice and assistance. I appreciate the constructive comments on a draft of this paper by John Birks. Jenny Johnston assisted with artwork. 
Open Access This article is distributed under the terms of the Creative Commons Attribution 4.0 International License (http://creativecommons.org/licenses/by/4.0/), which permits unrestricted use, distribution, and reproduction in any medium, provided you give appropriate credit to the original author(s) and the source, provide a link to the Creative Commons license, and indicate if changes were made.

\section{References}

Armstrong JI, Calvert J, Ingold CT (1930) The ecology of the Mountains of Mourne with special reference to Slieve Donard. Proc R Ir Acad B39:440-452

Bibby HC (1940) The submerged forests at Rhyl and Abergele, North Wales. Data for the study of postglacial history. III. New Phytol 39:220-225

Birks HJB (1993) Precision, concepts, controversies: Alan Smith’s contributions to vegetational history and palaeoecology. In: Chambers FM (ed) Climate change and human impact on the landscape. Chapman \& Hall, London, pp 5-21

Birks HJB (2005) Fifty years of Quaternary pollen analysis in Fennoscandia 1954-2004. Grana 44:1-22

Birks HJB (2017) Herbert E. Wright Jr, 1917-2015. Biographical memoirs. http://www.nasonline.org/publications/biographicalmemoirs/memoir-pdfs/wright-herbert.pdf. Accessed 10 Apr 2017

Birks HJB, Birks HH (2007) Winifred Tutin (1915-2007). J Paleolimnol 38:601-605

Birks HJB, Birks HH, Ammann B (2016) The fourth dimension of vegetation: 100 years ago, Lennart von Post first used pollen analysis to reconstruct past ecosystems. Science 354:412-413

Boney AD (1995) The botanical 'Establishment' closes ranks: fifteen days in January 1921. Linnean 11(3):26-37

Brown M (2013) ILP@ 120: Arthur Raistrick-the Dales' own man of peace. http://www.independentlabour.org.uk/main/2013/09/12/ ilp120-arthur-raistrick-\%E2\%80\%93-the-dales\%E2\%80\%99own-man-of-peace/. Accessed 10 Apr 2017

Burge HA (2002) An update on pollen and fungal spore aerobiology. J Allergy Clin Immunol 110:544-552

Burrell WH (1924) Pennine peat. Naturalist 808:145-150

Cameron AD (2007) A brief history of forestry teaching and research at the University of Aberdeen. https://homepages.abdn.ac.uk/ forestry/associated $\% 20$ links/Brief\%20history $\% 20$ of $\% 20$ forestry\%20at\%20Aberdeen\%20vs\%202014.pdf. Accessed 10 Apr 2017

Chandler MEJ (1921) The Arctic flora of the Cam Valley at Barnwell, Cambridge. Q J Geol Soc Lond 77:4-22

Cheetham CA (1925) Yorkshire naturalists' union: botanical section. Naturalist 826: 340-341

Chesters CGC (1931) On the peat deposits of Moine Mhor. J Ecol 19:46-59

Clapham AR, Clapham BN (1939) The valley fen at Cothill, Berkshire. Data for the study of post-glacial history. II. New Phytol 38:167-174

Cross AT, Kosanke RM (1995) History and development of Carboniferous palynology in North America during the early and middle twentieth century. In: Lyons PC, Morey ED, Wagner RH (eds) Historical perspective of early twentieth century carboniferous paleobotany in North America. In memory of William Culp Darrah, vol 185. Geological Society of America, Boulder, pp 353-387

Davies EG (1945) Blaen Brefi: a Welsh upland bog. J Ecol 32:147-166

Deevey ES (1967) Introduction. In: Martin PS, Wright HE (eds) Pleistocene extinctions. Yale University Press, New Haven, pp 63-72
Demchuk TD, Riding JB (2008) A history and overview of the American Association of Stratigraphic Palynologists (AASP). Palynology 32:83-100

DNB (2004) Jennings B, Raistrick A (1896-1991). Oxford Dictionary of national biography, Oxford University Press, Oxford. http:// www.oxforddnb.com/view/article/49936. Accessed 10 Apr 2017

DNB (2011) West RG, Pennington WA (1915-2007). Oxford Dictionary of national biography, Oxford University Press, Oxford. http://www.oxforddnb.com/view/article/98836. Accessed $10 \mathrm{Apr}$ 2017

Edlund AF, Winthrop ZA (2014) Sharing what he saw: an appreciation of Gunnar Erdtman's life and illustrations. Grana 53:1-21

Edwards KJ (1983) Quaternary palynology: consideration of a discipline. Progr Phys Geogr 7:112-125

Edwards KJ (1986a) Professor Sir Harry Godwin F.R.S., 1901-1985, a tribute. J Archaeol Sci 13:299-306

Edwards KJ (1986b) Palynologists and progress-transatlantic perspectives. Progr Phys Geogr 10:81-99

Edwards KJ (1992) Jørgen Troels-Smith, 1916-1991—a tribute. J Archaeol Sci 19:477-482

Edwards KJ, Fyfe RM, Hunt CO, Schofield JE (2015) Moving forwards? Palynology and the human dimension. J Archaeol Sci 56:117-132

Edwards KJ, Fyfe RM, Jackson ST (2017) The first 100 years of pollen analysis. Nat Plants 3:17,001. https://doi.org/10.1038/ nplants.2017.1

Erdtman G (1920) Einige geobotanische Resultate einer pollenanalytischen Untersuchung von südwestschwedischen Torfmooren. Svensk Botan Tidskr 14:292-299

Erdtman G (1921) Pollenanalytische Untersuchungen von Torfmooren und marinen Sedimenten in Südwest-Schweden. Arkiv Botan $17: 1-173$

Erdtman G (1923) Iakttagelser fråm en mikropaleontologisk undersökning at nordskotska, Hebridiska, och Shetländska torvmarker Geol Fören Stockh Förh 45:538-545

Erdtman G (1924a) Studies in micropalaeontology of Post-glacial deposits in Northern Scotland and the Scotch Isles, with especial reference to the history of the woodlands. J Linn Soc (Bot) 46: 449-504

Erdtman G (1924b) Mitteilungen über einige irische Moore. Svensk Botan Tidskr 18:451-459

Erdtman G (1925) Pollen statistics from Curragh and Ballaugh, Isle of Man. Proc Liverpool Geol Soc 14:158-163

Erdtman G (1926) Några drag ur de irländska skogarnas postarktiska historia. Svensk Botan Tidskr 20:483-485

Erdtman G (1927) Traces of the history of the forests of Ireland. Ir Nat J 1:242-245

Erdtman G (1931) The boreal hazel forests and the theory of pollen statistics. J Ecol 19:158-163

Erdtman G (1943) An introduction to pollen analysis. Chronica Botanica, Waltham

Erdtman G (1967) Glimpses of palynology: 1916-1966. Rev Palynol Palaeobot 1:23-29

Fægri K (1973) In memoriam O. Gunnar E. Erdtman 1897-1973. Pollen Spores 15:5-12

Fægri K, Iversen J (1950) Text-book of modern pollen analysis. Ejnar Munksgaard, Copenhagen

Fægri K, Iversen J (1967) Introduction to von Post L, Forest tree pollen in south Swedish peat bog deposits. Pollen Spores 9:375-377

Fara P (2004) Pandora's breeches: women, science and power in the Enlightenment. Pimlico London

Fisher WB (1975) Public oration for Harry Godwin, Hon D. Sc. University Durham Gazette 11:38

Fraser GK (1933) Studies of Scottish moorlands in relation to tree growth. Forestry Commission Bulletin No. 15. HMSO, London 
Fraser GK (1943) Peat deposits of Scotland Part I. Wartime Pamphlet No. 36, Department of Scientific and Industrial Research, Geological Survey of Great Britain, Scotland

Fraser GK, Godwin H (1955) Two Scottish pollen diagrams: Carnwath Moss, Lanarkshire and Strichen Moss, Aberdeenshire. Data for the study of post-glacial history. XVII. New Phytol 54:216-221

Fries M (1967) Lennart von Post's pollen diagram series of 1916. Rev Palaeobot Palynol 4:9-13

Gargiulo F, Lambiotte CA, Carletti T (2016) The classical origin of modern Mathematics. EPJ Data Sci 5:26. https://doi.org/10.1140/ epjds/s13688-016-0088-y

Gillson L (2015) Biodiversity conservation and environmental change: using palaeoecology to manage dynamic landscapes in the Anthropocene. Oxford University Press, Oxford

Godwin H (1973) Obituary: tribute to four botanists. New Phytol $72: 1,245-1,250$

Godwin H (1981) The archives of the peat bogs. Cambridge University Press, Cambridge

Godwin H (1985) Cambridge and Clare. Cambridge University Press, Cambridge

Godwin H, Godwin ME (1933a) British Maglemose harpoon sites. Antiquity 7:36-48

Godwin H, Godwin ME (1933b) Pollen analyses of Fenland peats at St. Germans, near King's Lynn. Geol Mag 70:168-180

Godwin H, Godwin ME (1940) Submerged peat at Southampton. Data for the study of post-glacial history. V. New Phytol 39:303-307

Godwin H, Mitchell GF (1938) Stratigraphy and development of two raised bogs near Tregaron, Cardiganshire. New Phytol $37: 425-454$

Godwin H, Newton L (1938) The submerged forest at Borth and Ynyslas, Cardiganshire. Data for the study of post-glacial history. No. I. New Phytol 37:333-344

Godwin H, Richards PW (1946) Note on the occurrence of Meesia triquetra (Hook and Tayl.) Aongstr. in post-glacial peat in Somerset (England). Rev Bryol Lichén 15:123-130

Goodchild H (1920) More about "Moorlog"- a peaty deposit from the Dogger Bank in the North Sea. Essex Nat 19:242-250

Grant M, Waller M (2017) Resolving complexities of pollen data to improve interpretation of past human activity and natural processes. In: Williams M, Hill T, Boomer I, Wilkinson IP (eds) The archaeological and forensic applications of microfossils: a deeper understanding of human history. Special Public of the Micropalaeontological Society, Geological Society Publishing House, Bath, pp 103-119

Hardy EM (1939) Studies of the post-glacial history of British vegetation. V. The Shropshire and Flint Maelor mosses. New Phytol 38:364-396

Harrison SG (1974) Harold Augustus Hyde (1892-1973). Watsonia 10:113-114

Hart JK (2007) The role of women in British Quaternary science. In: Burek CV, Higgs B (eds) The role of women in the history of geology, vol 281. Special Publications-The Geological Society, London, pp 83-95

Hart AL (2017) Kathleen Bever Blackburn: a distinguished British botanist. Northumbrian Nat (in press)

Haworth EY, Lund JWG (eds) (1984) Lake sediments and environmental history: studies in palaeolimnology and palaeoecology in honour of Winifred Tutin. Leicester University Press, Leicester

HEFCE (2017) REF impact. http://www.hefce.ac.uk/rsrch/REFimpact/. Accessed 10 Apr 2017

Hodgson LM (1933) The distribution of woodland, present and past, in the Nant Ffrancon valley and other parts of Caernarvonshire. Unpublished MSc Thesis, Univ of Wales, Bangor

Holst NO (1909) Postglaciala tidsbestämningar. Sveriges Geol Undersökn, Ser C: Avhandl och Uppsat No. 216
Hyde HA (1936) On a peat bed at the East Moors, Cardiff. Trans Cardiff Nat Soc 69:39-48

Hyde HA, Adams KF (1958) An atlas of airborne pollen grains. Macmillan, London

Hyde HA, Williams DA (1944) The right word. Pollen Anal Circ 8:6

Iversen J (1941) Landnam i Danmarks Stenalder. Land occupation in Denmark's Stone Age. Danm Geol Unders Ser II 66:1-68

Iversen J (ed) (1954) Studies in vegetational history in honour of Knud Jessen 29th November 1954. Damn Geol Unders Ser II 80:1-308

Jenkin BM, Mortimer CH, Pennington W (1941) The study of lake deposits. Nature 147:496-500

Jessen K (1936) Palæobotanical report on the Stone Age site at Newferry, County Londonderry. Appendix I in Movius HL, A Neolithic site on the River Bann. Proc R Ir Acad 43C:31-37

Jessen K (1949) Studies in Late Quaternary deposits and flora-history of Ireland. Proc R Ir Acad 52B:85-290

Jessen K, Farrington A (1938) The bogs at Ballybetagh, near Dublin, with remarks on Late-glacial conditions in Ireland. Proc R Ir Acad 44B:205-260

Jonsell B (2007) Svensk botanisk forskning under 1900-talet. Svensk Botan Tidskr 101:19-54

Kertland MPH (1928) The ecology of Divis. J Ecol 16:301-322

Knox EM (1938) The spores of Pteridophyta, with observations on microspores in coals of Carboniferous age. Bot Soc Edinburgh Trans Proc 32(3):438-466

Knox EM (1954) Pollen analysis of a peat at Kingsteps Quarry, Nairn. Trans Bot Soc Edinb 36:224-229

Köbl-Ebert M, Turner S (2016) Towards a history of women in the geosciences. In: Meyer W, Clary RM, Azuela LF, Mota TS, Wołkowicz $S$ (eds) History of geoscience: celebrating 50 years of INHIGEO, vol 442. Special Publications-The Geological Society, London, pp 205-216

Kosanke RM, Cross AT (1995) Leonard Richard Wilson (1906-): palynologist, paleobotanist, and geologist. In: Lyons PC, Morey ED, Wagner RH (eds) Historical perspective of early twentieth century carboniferous paleobotany in North America. In memory of William Culp Darrah, vol 185. The Geological Society of America, Boulder, pp 237-244

Kullman L (2001) Immigration of Picea abies into North-Central Sweden. New evidence of regional expansion and tree-limit evolution. Nord J Bot 21:39-54

Kullman L (2008) Early postglacial appearance of tree species in northern Scandinavia: review and perspective. Quat Sci Rev $27: 2,467-2,472$

La Touche CJ (1936) Occurrence of pollen of Carpinus (Hornbeam) in Irish peat. Nature 137:949

Linton WD (1977) Miss M.P.H. Kertland. Honorary editor 19511976. An appreciation. Ir Nat J 19:1-2 and frontispiece

Linton WD (1992) Mary Patricia Happer Kertland (1902-1991). Watsonia 19:64-65

Lunn AG (1983) Physical geographers, Quaternary geologists and conservationists. In: Lunn AG (ed.) A history of naturalists in North East England. Dept of Adult Education, University of Newcastle upon Tyne, Newcastle, pp 81-93

MacDonald GM, Bennett KD, Jackson ST, Parducci L, Smith FA, Smol JP, Willis KJ (2008) Impacts of climate change on species, populations and communities: palaeobiogeographical insights and frontiers. Progr Phys Geogr 32:139-172

Mahr A (1934) A wooden cauldron from Altartate, Co. Monaghan. Proc R Ir Acad C 42:11-29

Manten AA (1966) Half a century of modern palynology. Earth Sci Rev 2:277-316

Manten AA (1967) Lennart von Post and the foundation of modern palynology. Rev Palaeobot Palynol 1:11-22

Manten AA (1970) Statistical analysis of a scientific discipline: palynology. Earth Sci Rev 6:181-218 
Marshall JEA (2005) Arthur Raistrick: Britain's premier palynologist. In: Bowden AJ, Burek CV, Wilding R (eds) History of palaeobotany: selected essays, vol 241. Geological Society London Special Publications, London, pp 161-179

McAndrews JH (1973) Gunnar Erdtman's last pollen diagram; location, location, location. Can Assoc Palynol Newsl 29:8-9

Michell GF (1951) Studies in Irish Quaternary deposits No. 7. Proc R Ir Acad 53B:111-206

Mitchell GF (1940) Some lacustrine deposits near Dunshaughlin, County Meath. Proc R Ir Acad 46B:13-37

Mitchell GF (1956) Post-Boreal pollen-diagrams from Irish raisedbogs. (Sudies in Irish Quaternary deposits: No. 11.). Proc R Ir Acad 57B: $185-251$

Mitchell F (1976) The Irish landscape. Collins, London

Mitchell GF (1984) Development of Quaternary palaeobotany. Quat Newsl 43:24-30

Mitchell F (1990) The way that I followed: a naturalist's journey around Ireland. Country House, Dublin

Mitchell GF and Parkes HM (1949) The Giant Deer in Ireland. (Studies in Irish Quaternary Deposits, No. 6). Proc R Ir Acad 52B:291-314

Mitchell GF, Scannell MJP (1995) Obituary. Hilda Marion Parkes (1916-1992). Ir Nat J 25:41-44

Mullins G (2007) Dublin Nazi No. 1: the life of Adolf Mahr. Liberties Press, Dublin

Nilsson S, Ukraintseva V, El-Ghazaly G (1993) Professor Gunnar Erdtman (1897-1973). Grana Suppl. 2:1-2

Nordlund C (2014) Peat bogs as geological archives: Lennart von Post et al., and the development of quantitative pollen analysis during World War I. Earth Sci Hist 33:187-200

Parducci L, Bennett KD, Ficetola GF, Alsos IG, Suyama Y, Wood JR, Pedersen MW (2017) Ancient plant DNA in lake sediments. New Phytol. https://doi.org/10.1111/nph.14470

Parkes HM (1975) Records of Codium species in Ireland. Proc R Ir Acad 75B:125-134

Parkes HM, Bradshaw R (1988) Bloomhill pollen analysis. In Breen TC, Excavation of a roadway at Bloomhill Bog, County Offaly. Proc R Ir Acad 88C:335-339

Parkes HM, Mitchell FJG (2000) Vegetation history at Clonmacnoise, Co. Offaly. Biol Environ 100B:35-40

Pearsall WH (1940) Thomas William Woodhead. An appreciation. Naturalist 65:157-158

Pennington W (1943) Lake sediments: the bottom deposits of the North Basin of Windermere, with special reference to the diatom succession. New Phytol 42:1-27

Pennington W (1947) Lake sediments; pollen diagrams from the bottom deposits of the north basin of Windermere. Philos Trans R Soc Lond B 233:137-175

Praeger RL, Farrington A, Jessen K, Blake Whelan C, Mahr A, Clark JGD (1934) The Committee for Quaternary Research in Ireland and its work. Ir Nat J 5:126-152

Precht J (1953) On the occurrence of the "Upper Forest layer" around Cold Fell, N. Pennines. Trans North Nat Union 2:44-48

Raistrick A (1932) The pollen analysis of peat. Naturalist 905:177-182

Raistrick A (1938) The microspore content of some Lower Carboniferous coals. Trans Leeds Geol Assoc 5:221-226

Raistrick A (1943) Teach yourself geology. English Universities Press, London

Raistrick A, Blackburn, KB (1931) Pollen analysis of the peat on Heathery Burn Moor, Northumberland. Proc Univ Durham Philos Soc 8:351-358

Raistrick A, Blackburn KB (1932) Analysis of some Lake District peats. North West Nat 7:94-97

Raistrick A, Blackburn KB (1933) The late-Glacial and post-Glacial periods in the North Pennines. Part III, The post-glacial peats. Trans North Nat Union 1(for 1932):79-103
Raistrick A, Simpson J (1933) The microspores of some Northumberland coals, and their use in the correlation of coal-seams. Trans Inst Min Eng 85:225-235, 86:55

Raistrick A, Woodhead TW (1930) Plant remains in post-glacial gravels near Leeds. Naturalist 877:39-44

Reid C (1913) Submerged forests. Cambridge University Press, Cambridge

Reid C, Reid EM (1909) Note on the plant remains by Mr. Clement Reid, F.R.S., and Mrs. Reid. In: Whitehead H, Goodchild HH (eds) Some Notes on "Moorlog," a peaty deposit from the Dogger Bank in the North Sea. Essex Naturalist 16:54-56

Riding JB, Dettmann ME (2014) The first Australian palynologist: Isabel Clifton Cookson (1893-1973) and her scientific work. Alcheringa 38:97-129

Riding JB, Chaloner WG, Farley MB, Rich FJ, Strother PK (2016) A biography and obituary of Alfred Traverse (1925-2015). Palynology 40:iii-xi

Roberts N (2014) The Holocene: an environmental history, 3rd edition. Wiley, Chichester

Salisbury EJ (1922) Botany. Sci Progr Twentieth Century 16:551-554

Salisbury EJ (1964) The origin and early years of the British Ecological Society. J Ecol 52(Suppl.):13-18

Samuelsson G (1910) Scottish Peat Mosses. A contribution to the knowledge of the late-quaternary vegetation and climate of North-Western Europe. Bull Geol Inst Univ Upsala 10:197-260

Schlickum R (1953) Ulrich Steusloff (1883-1953). Arch Moll $82: 158-161$

Selling OH (1951) Lennart von Post 16/6 1884-11/1 1951. Svensk Botan Tidskr 45:275-296

Seward AC (1898-1919) Fossil plants. A text-book for students of botany and geology. 4 volumes, Cambridge University Press, Cambridge

Seward AC, Reid EM, Boswell PGH, Chandler MEJ, Godwin H, Wilmott AJ, Salisbury EJ, Raistrick A, Du Rietz GE, Watson W, Simpson GC, Dewey, Simpson JB, Sandford KS, Butcher RW, Wright WB, Hamshaw Thomas H, Burkitt M, Burtt Davy J, Turrill WB, Watt AS, Hollingworth (1935) Discussion on the origin and relationship of the British flora. Proc R Soc Lond B 118:197-241

Sheail J (1987) Seventy-five years in ecology: the British Ecological Society. Blackwell Scientific, Oxford

Sheail J (1988) T.W. Woodhead and the study of vegetation and man in the Huddersfield district. Naturalist 113:125-139

Shetterly ML (2016) Hidden figures. William Morrow, New York

Simms A (1982) Die historische Geographie in grossbritannien 'A personal view'. Erdkunde 36:71-80

Simpson JB (1934) Fossil pollen in Scottish Jurassic coal. Nature 139:673

Simpson JB (1961) The Tertiary pollen-flora of Mull and Ardnamurchan. Trans R Soc Edinb 64:421-468

Smith PJ (1997) Grahame Clark's new archaeology: the Fenland Research Committee and Cambridge prehistory in the 1930s. Antiquity 1997:11-30

Smith AG, Pilcher JR (1973) Radiocarbon dates and vegetational history of the British Isles. New Phytol 72:903-914

Steusloff U (1905) Torf- und Wiesenkalk-Ablagerungen im Rederangund Moorsee-Becken. Ein Beitrag zur Geschichte der Muritz. Arch Ver Fr Naturgesch Mecklenburg 59:147-210

Stout A (2009) Creating history: druids, ley hunters and archaeologists in pre-War Britain. Wiley, Chichester

Szafer W (2017) https://pl.wikipedia.org/wiki/Władysław_Szafer. Accessed 10 Apr 2017

Ting S (1937) Studies of the Scottish shoreline. Unpublished PhD Thesis, Univ of Glasgow

Ting S (1949) Illustrations of pollen grains of some Chinese plants. Bot Not 4:277-282 
Ting WS (1965) The saccate pollen grains of Pinaceae mainly of California. Grana Palynol 6:270-289

Travis CB (1926) The peat and forest bed of the southwest Lancashire coast. Proc Liverpool Geol Soc 14:263-277

Travis CB (1929) The peat and forest beds of Leasowe, Cheshire. Proc Liverpool Geol Soc 15:157-178

Troels-Smith J (1975) Knud Jessen Nov. 29th 1884-April 14th 1971. Bull Geol Soc Denm 24:99-111

Valentine DH (1970) Kathleen Bever Blackburn. Watsonia 8:69-74

Von Post L (1910) Das Skagershultmoor. In: Post L von, Sernander $\mathrm{R}$ (eds) Pflanzenphysiognomische Studien auf Torfmooren in Närke. Intern. Geol. Congr., llth, Stockholm, Congr. Guide 14 (Excursion A7), pp 1-24

Von Post L (1916a) Om skogsträdpollen i sydsvenska torvmosselagerföljder. Geol Fören Stockh Förh 38:384-394

Von Post L (1916b) Einige südschwedischen Quellmoore. Bull Geol Inst Univ Upsala 15:219-278

Von Post L (1918) Skogsträdspollen i sydsvenska torvmosselagerföljder. Forhandlinger ved de skandinaviske naturforskeres 16. Möte i Kristiania den 10-15 juli 1916, pp 432-465

Von Post L (1924) Ur de sydsrenska skogarnas regionala historia under post-arktisk tid. Geol Fören Stockh Förh 46:83-128

Von Post L (1926) Einige Aufgaben der regionalen Moorforschung. Sveriges Geol Unders Ser C Avhandl Uppsat 337:1-41

Von Post L (1944) Pollenstatistika perspektiv på Jordens klimathistoria. Ymer 64:79-113

Von Post L (1946) The prospect for pollen analysis in the study of the earth's climate history. New Phytol 45:193-217

Von Post L (1967) Forest tree pollen in south Swedish peat bog deposits. Translation by Davis MB, Fægri K, introduction by Fægri K, Iversen J. Pollen Spores 9:375-401

Watts W (2008) Provost Trinity College Dublin. A memoir. Lilliput/ Hinds, Dublin

Watts WA, West RG (1999) George Francis Mitchell. 15 October 1912-25 November 1997. Biog Mem Fellows R Soc 45:316-328
Weber CA (1900) Ueber die Moore, mit besonderer Berücksichtigung der zwischen Unterweser und Unterelbe liegenden. Jahresber. Männer Morgenstern 3:3-23

Welinder S (1988) Review of H Göransson, Neolithic man and the forest environment around Alvastra Pile Dwelling. Norw Arch Rev 21:129-130

West RG (2014) Quaternary research in Britain and Ireland. A history based on the activities of the Subdepartment of Quaternary Research, University of Cambridge, 1948-1994. Sidestone Press, Leiden

West RG (2017) Richard West. http://www.bl.uk/voices-of-science/ interviewees/richard-west. Accessed 10 Apr 2017

White JM (1931) Pollen analysis of peat from Stoneyisland, Portumna, Co. Galway. Ir Nat J 3:210-214

Willis AJ (1997) The ecosystem: an evolving concept viewed historically. Funct Ecol 11:268-271

Wiltshire PEJ, Hawksworth DL, Edwards KJ (2015) A rapid and efficient method for evaluation of suspect testimony: palynological scanning. J Foren Sci 60:1,441-1,450

Withers CWJ (2015) Afterword: geographers, historical geographies, war. J Hist Geogr 47:89-93

Wood RF (1974) Fifty years of forestry research. A review of work conducted and supported by the Forestry Commission, 1920-1970. Forestry Commission Bulletin No. 50. HMSO, London

Woodhead TW (1906) Ecology of woodland plants in the neighbourhood of Huddersfield. J Linn Soc Bot 37:333-406

Woodhead TW (1924) The age and composition of Pennine peat. J Bot 62:301-304

Woodhead TW (1929) History of the vegetation of the Southern Pennines. J Ecol 17:1-34

Woodhead TW, Erdtman OGE (1926). Remains in the peat of the Southern Pennines. Naturalist 835:245-253

Woodhead N, Hodgson LM (1935) A preliminary study of some Snowdonian peats. New Phytol 34:263-282 